\title{
Improving the quality of university library services to meet the requirements of basic educational quality accreditation
}

\author{
Au Thi Cam Linh ${ }^{1 *}$, Le Anh Tu ${ }^{1}$ \\ ${ }^{1}$ The Ho Chi Minh City Open University Library, Vietnam \\ *Corresponding author: linh.atc@ou.edu.vn
}

\begin{abstract}
ARTICLE INFO
ABSTRACT

DOI: $10.46223 / \mathrm{HCMCOUJS.}$

soci.en.10.1.572.2020

Received: May $3^{\text {rd }}, 2020$

Revised: May $10^{\text {th }}, 2020$

Accepted: May $24^{\text {th }}, 2020$

Keywords:

university library, library services, service quality, quality accreditation, service quality assessment

This paper examines the results of quality accreditation of library criteria retrieved from universities (according to the set of standards issued by the Ministry of Education and Training) from 2016 to the present. By studying the limitations of libraries, recommendations from external organizations for quality accreditation and identifying the causes, the authors propose solutions to improve the quality of university library services. Proposed solutions involve the library's initiative in understanding user needs and providing services that meet the needs of learners and stakeholders, carrying out good management of libraries and periodically surveying users to better the quality of library services.
\end{abstract}

\section{Introduction}

A university library is an affiliated unit that bears the responsibility of contributing to the university's success. All library activities aim to contribute to the university's goals.

After Vietnam Law on Education (National Assembly of Vietnam, 2005) regulated educational quality accreditation, Vietnamese universities began their preparation for quality assessment including both internal and external evaluation. From 2015 to 2020, they actively evaluated educational institutions and training programs according to different sets of standards. To survive, they ought to ensure quality and be recognized by law. Being an affiliated unit, a library should inevitably contribute to the quality achieved by the university. The quality of library services additionally contributes to the university's competitiveness. Herein lies the problem: How can Vietnamese university libraries meet the requirements of quality accreditation while simultaneously fulfilling their main purpose of providing a quality service to users?

It is necessary to examine the results of quality accreditation of library criteria and propose solutions for libraries to meet the requirements of accreditation. Relevant to this paper is the article of Pham and Hoang (2017) which internally analyzed the library criterion. Based on empirical evidence of accreditation carried out at the University of Agriculture library, the authors pointed out some reasons and solutions being implemented in this university. To make a more complete basis and propose solutions for university libraries to meet the requirements of quality accreditation, this paper examines the assessment results of library criteria retrieved from 136 universities from 2016 to the present. The content only refers to service quality based on the requirements of quality accreditation of library service in tertiary institutions. 


\section{Literature review}

\subsection{Definitions of quality}

There has been no consensus on the definition of quality due to various ways of comprehension. According to one of the widely accepted definitions made by the International Standard on Quality Management Systems - ISO 9000, quality is "the degree to which a set of inherent characteristics fulfills a need or expectation that is stated, generally implied or obligatory" (Hoyle, 2006). It is, on the contrary, defined in the Oxford dictionary as "the standard of something as measured against other things of a similar kind; the degree of excellence of something" (Lexico.com, n.d.).

Grönroos (1982) claimed that human beings can only "(1) determine the quality of service as perceived by consumers and (2) determine how the quality of service affects consumers" (p. 27). Grönroos (1982) developed a model in which he argued that, when evaluating service quality, consumers compare the service expected with perceptions of service received. From the viewpoints of Lewis and Booms (1983), "service quality is the measurement of how a provided service meets a customer's expectations. Providing a quality service is to meet a customer's expectations on a consistent basis" (p. 101). Parasuraman, Zeithaml, and Berry (1985) introduced a customer-based approach to conceptualizing and measuring service quality. A couple of years later, Parasuraman and his colleagues developed SERVQUAL with 05 dimensions: Tangibles, Reliability, Responsiveness, Assurance, Empathy with a questionnaire of 22 item instruments (Parasuraman, Zeithaml, \& Berry, 1988). The measurement was continuously tested by other scholars in subsequent years to suit different service industries.

\subsection{Quality of library services from the librarian's point of view}

The quality of a university library was previously described by collections. It is measured by the scale of the library-owned resources and the number of users (Nitecki, 1996). From the 1990s onwards, there has been a gradual change in the approach to library service quality. Specialists in the field of library science examined the quality models by Parasuraman, Berry, and Zeithaml and suggested that "this approach emphasizes the service nature of libraries" (Nitecki, 1996, p. 85). It possibly helps library managers monitor users in terms of expectations and systemic perceptions. This framework is used by libraries to improve services in the direction of a better response. Based on SERVQUAL, the Association of Research Libraries (ARL) and Texas A \& M University developed LibQUAL with 03 dimensions: Information Control - IC (8 queries); Affect Service - AS (9 queries); Library as a Place - LP (5 queries) being used by many libraries worldwide, including university libraries (Association of Research Libraries, 2020).

Pymm (1998) argues that to establish quality library services, libraries need to (1) understand user needs; (2) provide the right services; (3) improve the service delivery system in terms of consistency and timely manner; (4) balance the books; and (5) build-up organizational and staff commitments.

From the perspective of educational quality accreditation, a university library is an affiliated unit, so it must contribute to achieving the university's goals. According to Atkinson (2016), "Updated to the new environment, academic librarians will need to adopt (and embrace) new approaches and methodologies to assess and improve the quality and performance of their services and be able to demonstrate to their customers and managers the relevance and value of their services" (p. 13). In this demanding, performance-driven environment, there are two key challenges for library managers: They need to create a culture of assessment amongst their staff and their users (Atkinson, 2016; Lakos \& Phipps, 2004) and they need to ensure that they and their 
staff are embedded with the rest of the university at all levels (Atkinson, 2016; Dewey, 2004).

\subsection{Quality of a university library is to meet the requirements of quality accreditation prescribed by law}

The concept of Vietnam's educational quality is stated in the article 2 of the Circular No. 12/2017/TT-BGDĐT dated 19 May 2017 by Ministry of Education and Training (2017):

Quality of tertiary educational institutions is to meet the goals set by these institutions, to ensure the requirements of educational goals prescribed by the Law on Tertiary Education, to be in line with the requirements of training human resources for the socio-economic development of localities and the whole country.

Quality assessment of tertiary educational institutions is to collect and process information, to make judgements based on evaluation criteria for all activities carried out by those institutions, including: quality assurance for strategy, quality assurance for system, and quality assurance for functional performance and operational results of educational institutions.

Quality accreditation of tertiary educational institutions is the assessment and recognization of the extent to which educational institutions has met the educational quality standards promulgated by the Minister of Education and Training.

The evaluation criteria for quality of educational institutions is the degree of requirements and conditions to be met in a specific aspect of each standard.

Educational quality accreditation was prescribed by the Law on Education (article 17, National Assembly of Vietnam, 2005). Quality assessment of tertiary education was prescribed more clearly in the Law on Higher Education, chapter VII (from article 49 to article 53, National Assembly of Vietnam, 2012), as amended and supplemented by the Law on Higher Education 2018 (National Assembly of Vietnam, 2018). Based on Law on higher education, Minister of Education and Training issued Decision 65/2007/QĐ-BGDĐT dated 01 November 2007 on Promulgating regulations on criteria for assessing the education quality of the university. The decision was amended and supplemented in the Circular 37/2012/TT-BGDĐT dated 30 October 2012 by the Minister of Education and Training (Ministry of Education and Training, 2012). The regulations were valid until July 3, 2017. However, schools that are implementing these regulations keep on their implementation until June 30, 2018. There are two levels of assessment: Satisfactory or Unsatisfactory.

According to the regulations, library-quality belongs to criteria 9, criterion 9.1: "A university library is full of books, textbooks, references written in Vietnamese and foreign languages to meet the requirements of officers, lecturers, and learners and possesses an internetconnected electronic library to serve the needs of teaching, learning, and scientific research with effectiveness" (Ministry of Education and Training, 2012). Detailed guidelines were issued in Official dispatch 527/KTKĐCLGD-KĐĐH dated 23 May 2013 of the Department of Assessment and Quality Accreditation on guidelines for the application of criteria in the assessment of the quality of a university (Department of Assessment and Quality Accreditation, 2013). Specifically, evidence that can be used for library criterion include:

- A written document of the library usage and service time;

- A user guide on electronic library and searching for electronic materials;

- Books, magazines, and references administrated by library management software; 
- A list of books, magazines, and references for the university's academic majors and scientific research;

- Statistics on the quantity and ratio of references, books, and magazines (serving each academic major) per lecturer and learner;

- A written commitment to regional universities which allows the exploitation of electronic library systems of regional or worldwide universities;

- The quantity statistics of worldwide scientific journals annually offered or available online;

- Annual statistics of library users (e.g., lecturers, officers, learners of which academic majors?);

- The quantity statistics of books, magazines, journals... borrowed or used annually according to each academic major;

- The number of books and materials updated annually;

- A report about an annual survey on the extent to which the library meets the usage requirements of officers, lecturers, and learners, including processes, tools, and results;

- Other relevant evidence.

In 2017, the Ministry of Education and Training issued Circular 12/2017/TT-BGDĐT dated 19 May 2017 on the Regulation on higher education accreditation as effective from the 4th of July 2017 (Ministry of Education and Training, 2017). This regulation is assessed by a 7-level rating scale as follows:

Level 1. Does not meet the criterion requirements

Level 2. Has not met the criterion requirements, more quality improvements are needed

Level 3. Meets the criterion requirements only when several improvements are made

Level 4. Fully meets the criterion requirements

Level 5. Meets above the criterion requirements

Level 6. Performs well as a model for the nation

Level 7. Performs extremely well, reaching the level of the world's leading educational institutions

According to this regulation, library-quality is mainly specified in part of criterion 7.4: "The system of planning, maintenance, assessment and enhancing the learning resources (such as library resources, teaching aids, online databases, etc.) to meet the needs of training, scientific research, and community service is set up and operated." (Ministry of Education and Training, 2017).

The assessment guidelines were issued together with Official dispatch 768/QLCLKĐCLGD dated 20 April 2018 by the Quality Control Department (Department of Assessment and Quality Accreditation, 2018). The department has replaced it by the latest assessment guidelines specified in Official dispatch 1668/QLCL-KĐCLGD dated 31 December 2019 (Department of Assessment and Quality Accreditation, 2019). Accordingly, libraries ought to meet the requirements to achieve level 4 as follows: 


\section{Table 1}

Citing the requirements of criterion 7.4 upon library and reference milestones to achieve level 4

\begin{tabular}{|c|c|c|}
\hline $\begin{array}{c}\text { Requirements of the } \\
\text { library-related } \\
\text { criterion }\end{array}$ & $\begin{array}{c}\text { Reference milestones to } \\
\text { achieve level } 4\end{array}$ & Hints for evidence sources \\
\hline $\begin{array}{l}\text { 1. The system of } \\
\text { planning, maintenance, } \\
\text { assessment, and } \\
\text { enhancing the learning } \\
\text { resources such as } \\
\text { library resources, online } \\
\text { databases to meet the } \\
\text { needs of training, } \\
\text { scientific research, and } \\
\text { community service is } \\
\text { set up. } \\
\text { 2. The system of } \\
\text { planning, maintenance, } \\
\text { assessment, and } \\
\text { enhancing the learning } \\
\text { resources such as } \\
\text { library resources, online } \\
\text { databases to meet the } \\
\text { needs of training, } \\
\text { scientific research, and } \\
\text { community service is } \\
\text { operated. }\end{array}$ & $\begin{array}{l}\text { 1. There is a department to } \\
\text { manage learning resources. } \\
\text { 2. Plans for investment and } \\
\text { maintenance of learning } \\
\text { resources such as library } \\
\text { resources, online databases } \\
\text { are issued. } \\
\text { 3. Educational institutions } \\
\text { have a new investment in } \\
\text { and maintenance of learning } \\
\text { resources such as library } \\
\text { resources, online databases } \\
\text { to meet the needs of } \\
\text { training, scientific research, } \\
\text { and community service. } \\
\text { 4. There are an annual } \\
\text { review and assessment of } \\
\text { the effectiveness } \\
\text { investment and maintenance } \\
\text { of learning resources such } \\
\text { as library resources, online } \\
\text { databases to meet the needs } \\
\text { of training, scientific } \\
\text { research, and community } \\
\text { service. } \\
\text { 5. Having data to monitor } \\
\text { and assess the effectiveness } \\
\text { of using learning resources } \\
\text { such as library resources } \\
\text { and online databases. } \\
6 \text {. Learning resources such } \\
\text { as library resources and } \\
\text { online databases } \\
\text { training, scientific research, } \\
\text { and community service are } \\
\text { updated. }\end{array}$ & $\begin{array}{l}\text { - A written document of } \\
\text { establishing/assigning tasks to the } \\
\text { learning resources management } \\
\text { department*. } \\
\text { - Plans for investment and } \\
\text { maintenance of learning resources } \\
\text { such as library resources, online } \\
\text { databases*. } \\
\text { - Projects/written documents on the } \\
\text { financial autonomy of an educational } \\
\text { institution or its department investing } \\
\text { in facilities. } \\
\text { - Statistics of funding needs for } \\
\text { learning resources such as library } \\
\text { resources, online databases for } \\
\text { training, scientific research, and other } \\
\text { activities of educational institutions in } \\
\text { the 5-year assessment cycle (based on } \\
\text { an annual estimate)*. } \\
\text { - Reports of assessing the } \\
\text { effectiveness of investment and } \\
\text { maintenance of learning resources } \\
\text { such as library resources, online } \\
\text { databases*. } \\
\text { - Reports of monitoring and } \\
\text { assessing learning resources such as } \\
\text { library resources, online databases for } \\
\text { training, scientific research, and } \\
\text { community service*. } \\
\text { - Survey results of the extent to } \\
\text { which a library meets the needs of } \\
\text { training, scientific research, and } \\
\text { community service. }\end{array}$ \\
\hline
\end{tabular}

Source: Quality Control Department (2019)

*Denotes compulsory requirements 


\section{Research methods}

\subsection{Analytical framework}

From the theoretical basis, the authors propose the hypothesis that a library will meet the requirements of accreditation when:

1) Meeting the needs of users and stakeholders including materials (printed and electronic) for learning, teaching, and scientific research; facilities in terms of physical library space and information technology infrastructure; and staff's serving attitude and knowledge.

2) Having a plan to carry out activities to meet the school's goals.

3) Annually assessing service quality and improving performance based on assessment results.

4) Leaders are prepared for accreditation works by examining the set of accreditation standards and familiarizing their staff with activities such as knowing strategic plans of the school and materials in line with the detailed outlines of training programs.

\subsection{Data collection methods}

The paper uses qualitative methods including a literature review and the expert method. In addition to scholarly theories, the authors focus on analyzing the evaluation results officially posted on the websites of Accreditation Centers for Educational Quality, along with recommendations. The expert method was conducted by interviewing 7 library managers.

\section{Research results}

According to the results published on the websites of 04 Accreditation Centers for Educational Quality in Vietnam, from 2016 to March 2020, 136 universities were evaluated in terms of quality of educational institutions, according to a set of standards issued by the Ministry of Education and Training. The number of assessed schools was 12 in 2016, 46 in 2017, 60 in 2018, 9 in 2019, and 9 in 2020. Amongst them, 117 schools were assessed according to the old set of standards, in contrast to the other 19 schools that apply the new set of standards.

Table 2

Quality evaluation results of criterion 9.1/7.4

\begin{tabular}{|l|c|c|}
\hline \multicolumn{1}{|c|}{ Results of criterion 9.1/7.4 } & Quantity of libraries & Proportion (\%) \\
\hline Satisfactory & 40 & 29.4 \\
\hline 4 to 4.4 & 8 & 5.9 \\
\hline Unsatisfactory & 77 & 56.6 \\
\hline 3 to 3.8 & 11 & 8.1 \\
\hline
\end{tabular}

Source: Summarized from the evaluation results by accreditation centers for educational quality

The results in Table 2 demonstrate that 48 libraries (35.3\%) meet the criterion 9.1/7.4, in contrast to the other 88 libraries $(64.7 \%)$. It should be noted that many libraries have not reached the standardized and given milestones.

Recommendations are sent from assessment foundations to 116 libraries that are both satisfactory and unsatisfactory to criterion 9.1 and 7.4 (a proportion of $85.3 \%$ ). 


\section{Table 3}

Criteria need improving by libraries

\begin{tabular}{|l|c|c|}
\hline \multicolumn{1}{|c|}{ Criteria } & $\begin{array}{c}\text { Quantity of libraries } \\
\text { that need improvement }\end{array}$ & $\begin{array}{c}\text { Proportion } \\
\text { (\%) }\end{array}$ \\
\hline $\begin{array}{l}\text { Increasing materials as compared to the detailed } \\
\text { outlines of the training modules and meeting the needs } \\
\text { of learning, teaching, and scientific research. }\end{array}$ & 90 & 66.2 \\
\hline $\begin{array}{l}\text { Developing electronic libraries, building electronic } \\
\text { databases, and digitizing materials }\end{array}$ & 33 & 24.3 \\
\hline Linking with domestic and foreign libraries & 32 & 23.5 \\
\hline Improving infrastructure & 29 & 21.3 \\
\hline Funding libraries & 17 & 12.5 \\
\hline $\begin{array}{l}\text { Linking intra-system and center libraries with libraries } \\
\text { at branches and faculties }\end{array}$ & 16 & 8.8 \\
\hline Making plans and process for material supplementation & 12 & 6.6 \\
\hline $\begin{array}{l}\text { Giving instructions and encouraging learners and } \\
\text { lecturers to exploit materials }\end{array}$ & 9 & 5.1 \\
\hline Abiding by copyright issues & 7 & 4.4 \\
\hline Surveying needs and satisfaction of users & 6 & 3.7 \\
\hline $\begin{array}{l}\text { Rearranging personnel; increasing capabilities of } \\
\text { library staff including professional qualifications, } \\
\text { skills, and attitudes. }\end{array}$ & 5 & \\
\hline $\begin{array}{l}\text { Purchasing new equipment or upgrading software to } \\
\text { meet the user needs }\end{array}$ & 4 & \\
\hline
\end{tabular}

Source: Summarized from the evaluation results by accreditation centers for educational quality

The accreditation of library-related criteria shows several limitations that need improving and of which material constraints make a quite large proportion. The library shortcomings are as follows:

- Regarding materials: 90 libraries $(66.2 \%)$ need to improve their material resources in terms of both printed and electronic. According to the recommendations of the accreditation centers for educational quality, libraries lack materials (1) in line with the detailed outlines of the training programs; (2) written in foreign languages; (3) related to books and specialized journals for research; (4) in digital formats; (5) due to the very low amount of copies per student.

- Regarding the infrastructure: The majority of Vietnamese universities encounter problems with facilities about which recommendations are generally made for the school. Although 29 libraries (21.3\%) get direct recommendations, the higher number needs to improve their facilities.

- Regarding the construction of electronic library: 33 libraries $(24.3 \%)$ do not meet this criterion and 4 libraries need to transfer to standardized software. This weakness results in their limitations in terms of providing grey literature, connecting to open educational resources, 
managing the library's data system, and connecting branches together.

- Regarding association with other libraries: 32 libraries $(23.5 \%)$ need to strengthen links with intra-system libraries and other domestic and foreign libraries in the same field.

- Regarding promotion activities and user guidance: 9 libraries $(6.6 \%)$ have not promoted the activities of supporting and encouraging users.

- Regarding the capabilities of library staff: 5 libraries $(3.7 \%)$ need to pay attention to rearranging personnel and increasing the capabilities of library staff including professional qualifications, skills, and attitudes.

- Regarding library management: 12 libraries (8.8\%) have not made a plan and process for material supplementation and digital library development; 6 libraries $(4.4 \%)$ have not conducted an annual survey on users as a basis for improving library services, have not reviewed and evaluated the effectiveness of collections, let alone the assessment of staff training; 7 libraries $(5.1 \%)$ have not paid attention to copyright issues in the delivery of library services.

- Regarding the university's investment in libraries: The external evaluation organization recommends not only higher investment in funding and infrastructure for 17 libraries but also more attention to the staff in 5 libraries.

\section{Causes of constraints:}

- Many libraries still lack long-term, medium-term, and annual plans but already have plans unincorporated with the requirements of accreditation criteria.

- Many activities have been organized by a library, except for the full keeping of evidence in 5 years. Still, the activities have not followed the PDCA model.

- There has been no close cooperation between faculties and a library in supplementing materials according to course syllabi. The library has not developed a material tracking system based on course syllabi to proactively supplement and update materials.

- Funding constraints in most universities have deep impacts on library improvement activities, most notably building facilities, applying information technology, and investing in book and magazine databases. Increasing the number of printed materials is directly proportional to the increase in funding and stack storage. Increasing the digital database means an increase in supplementation cost (annually ascending) and information technology infrastructure. Besides, some universities are not interested in investing in the library, demonstrated by the low allocation of funding, no equivalence between the library and other faculties, and unreasonable allocation of staff.

- This is the first accreditation cycle, so university libraries are inexperienced. In addition to the problem-solving at the institutional level, many university libraries lack the initiative in possible activities such as seeking association with other libraries in the same field or connecting system of internal libraries.

\section{Proposed solutions to the problem of improving the quality of library services to meet the requirements of quality accreditation of educational institutions}

\subsection{Designing and providing quality services}

- A library should understand the needs of lecturers, graduates, and undergraduates. To understand users' needs, it ought to conduct surveys and interviews, receive requests via email, 
and interact online. Upon the improvement according to recommendations by evaluation organizations, it is noted that the library must grasp the detailed outline of the training modules, make a list of subject materials and compare them with materials available in its stock. Missing materials are brought into a supplementation plan.

- After understanding the needs of users, the library plans for material supplementation, purchases equipment, adjusts opening hours, reviews how materials are served, actively digitalizes grey literature, promotes online service, and searches for open educational resources to introduce them on the website.

- The service and support system need to be smooth and easily accessible.

- Library staff is asked to serve with the highest responsibility and willingness and enlarge their knowledge to effectively support users.

\subsection{Managing library activities}

- Developing long-term, medium-term and annual plans are based on the school's general strategic plan. To develop a long-term or medium-term plan, not only the leaders but all the staff also need to understand the school's strategy. This helps the library to carry out activities in the right direction, without deviating from the school's goals. Simultaneously, it can proactively prepare for and propose an improvement of service quality that meets the quality accreditation implemented upon both educational institutions and training programs, because the university has different sets of evaluation criteria to choose.

An annual plan includes many plans that meet the requirements described in the Evaluation guide such as school year, material supplementation, material inventory, survey, procurement of equipment/supplies, maintenance, material removal, staff training, and organization of other activities.

An activity should be implemented through the following steps:

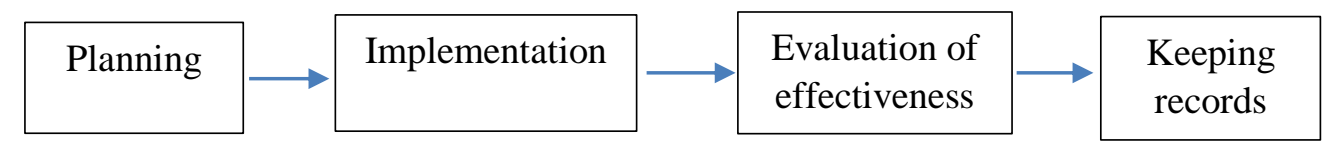

The plan is committed to paper (in the right manner). Other plans must be approved by the school leaders. It should be noted that keeping records needs both hard and soft copies. Systematizing records based on work or year facilitates the provision of phased evidence.

- Developing regulations and implementation process: A library needs to develop inadequate regulations and, especially, the supplementation and service processes. Annually, it needs to review and update the processes to suit the newer and more scientific regulations.

- Giving instructions and information to users: A library needs to implement integrated communication solutions such as organizing a tutorial class, delivering user guides, introducing library services via website, email, video, organizing reading contests, and so on.

- Improving the capabilities of library staff and building an internal quality culture: completion of the assigned work is at first. They must be thoroughly knowledgeable of accreditation standards to be well prepared for the accreditation of library criteria. To work effectively, library staff today ought to regularly update knowledge and practice skills including library and other fields' expertise, foreign languages, information technology, communication skills, and work organization and management. To boost the staff's improvement, leaders have to 
take the initiative in building and proposing plans to the school.

- Coordination and association:

- Internal coordination: A library should not wait for a rendezvous with any faculty, but proactively contact the faculty for material needs and a mutual review of any subject's list of materials. It also needs to update new course materials so that lecturers review and change the materials due to their unavailability in the market.

- Library association: A library should proactively search for another in the same field to discuss contents suitable for both libraries and propose the school to sign a cooperation agreement.

\subsection{Evaluating service quality and user satisfaction}

A library can choose a scale that matches its conditions. If a survey is conducted by the library, the process should be developed according to the PDCA model: Planning, making questionnaires and surveying, processing data, reporting results, delivering reports to relevant departments of the school, planning improvements or proposing improvement plans to relevant departments, reporting improvement results, and keeping full records.

\section{Conclusion}

The research results show that a majority of Vietnamese university libraries have not met the requirements prescribed by the Ministry of Education and Training's sets of accreditation standards for educational institutions. Main limitations come from materials (both printed and electronic), facilities, library management and association, and cooperation between libraries and faculties in supplementing materials according to the detailed outline of any subject in course syllabi.

Through the research results, libraries are expected to figure out their strengths and weaknesses. They need to fix their limitations and better their preparation for later accreditation cycles concerning sets of accreditation standards publicized by the Ministry of Education and Training and international foundations.

Designing and providing quality services, in line with the requirements of educational quality accreditation in tertiary institutions, is the mission of university libraries. Quality services must meet the needs of users and stakeholders and are regularly evaluated for improvement. University libraries should have a profound understanding of the aforementioned needs to design and provide quality services under the requirements of accreditation criteria. Library management requires active leadership and the staff's contribution to planning, implementation, innovating evaluation, and evidence archiving.

\section{References}

Association of Research Libraries. (n.d.). Survey FAQs: How is the LibQUAL+® survey constructed and conducted? Retrieved April 5, 2020, from https://www.libqua1.org/about/about_survey/faq_survey

Association of Research Libraries. (2020). Learn about LibQUAL+ ${ }^{\circledR}$ presentation. Retrieved April 6, 2020, from https://www.libqual.org/about/about_survey/tools

Atkinson, J. (2016). Quality and the academic library: Reviewing, assessing and enhancing service provision. Amsterdam, Netherlands: Elsevier Science, Chandos Publishing Elsevier Ltd. 
Center for Education Accreditation - The University of Danang. (2017). Kết quả kiểm định chất luợng Truờng Đại hoc [University quality accreditation results]. Retrieved April 10, 2020, from http://cea.udn.vn/Detail.aspx?id=141

Trung tâm Kiểm định chất lượng giáo dục Hiệp Hội các trường đại học, cao đẳng Việt Nam. (n.d.). Kết quả kiểm định cấp co sở giáo dục [Result of accreditation at institutional level]. Retrieved April 10, 2020, from http://cea-avuc.edu.vn/vi/ket-qua-kiem-dinhchat-luong-coso-giao-duc-2/

Department of Assessment and Quality Accreditation. (2013). Official Dispatch 527/KTKĐCLGD-KĐĐH dated 23 May 2013 on guidelines for the application of criteria in the assessment of the quality of a university. Retrieved April 12, 2020, from https://vanbanphapluat.co/ official-dispatch-no-527-ktkdclgd-kddh-application-criteriaassessment-quality-university -2013

Department of Assessment and Quality Accreditation. (2018). Công văn số 768/QLCLKĐCLGD ngày 20 tháng 4 năm 2018 về việc huớng dẫn đánh giá theo bộ tiêu chuẩn đánh giá chất lương co sở giáo dục đại học [Official Dispatch 768/QLCL-KĐCLGD dated 20 April 2018 on guidelines for the evaluation according to the higher education quality assessment standards]. Retrieved April 12, 2020, from http://cea.vnu.edu.vn/sites/ default/files/attachments/4.15._cv_768_huong_dan_dgcl_csgd.pdf

Department of Assessment and Quality Accreditation. (2019). Công văn số 1668/QLCLKĐCLGD ngày 31/12/2019 của Cục Quản lý chất luợng - Bộ Giáo dục và Đào tạo về thay thế Bảng huớng dẫn đánh giá ban hành kèm theo Công văn số $768 / Q L C L$ KĐCLGD [Official Dispatch 1668/QLCL-KĐCLGD dated 31 December 2019 the replacement of evaluation guide issued together with the Official Dispatch 768/QLCL$K Ð C L G D]$. Retrieved April 10, 2020, from http://cea.vnuhcm.edu.vn/images/upload/website-1/Tin-tuc/1a-CV1668-thay-the-CV-76831.12.2019-.pdf

Dewey, B. I. (2004). The embedded librarian: Strategic campus collaborations. Resource Sharing \& Information Networks, 17(1/2), 5-17.

Grönroos, C. (1982). Strategic management and marketing in the service sector. Helsingfors, Finland: Swedish School of Economics and Business Administration.

Hoyle, D. (2006). ISO 9000: Quality systems handbook. Oxford, UK: Butterworth-Heinemann.

Lakos, A., \& Phipps, S. (2004). Creating a culture of assessment: A catalyst for organizational change. Portal: Libraries and the Academy, 4(3), 345-361. doi:10.1353/pla.2004.0052

Lewis, R. C., \& Booms, B. H. (1983). The marketing aspects of service quality. In L. Berry, G. Shostack \& G. Upah (Eds.), Emerging perspectives on services marketing (pp. 99-104). Chicago, IL: American Marketing Association Chicago.

Lexico.com. (n.d.). Meaning of quality in English. Retrieved April 5, 2020, from https://www.lexico.com/definition/quality

Ministry of Education and Training. (2007). Quyết định Số 65/2007/QĐ-BGDĐT Ban hành Quy định về tiêu chuẩn đánh giá chất luọng giáo dục truò̀ng đại học [Decision 65/2007/QĐBGDĐT dated 01 November 2007 on promulgating regulations on criteria for assessing the education quality of university]. Retrieved April 12, 2020, from http://vbpl.vn/TW/Pages/vbpq-toanvan.aspx?ItemID=13006\&Keyword=65/2007/Q\%C4\% 90\%E2\%80\%93BGD\%C4\%90T 
Ministry of Education and Training. (2012). Thông tu số 37/2012/TT-BGDĐT ngày 30/10/2012 của Bộ Giáo Dục và Đào Tạo [Circular 37/2012/TT-BGDĐT dated 30 October 2012 by the Minister of Education and Training]. Retrieved April 8, 2020, from http://vbpl.vn/bogiaoducdaotao/ Pages/vbpq-toanvan.aspx?ItemID=27936

Ministry of Education and Training. (2017). Circular No. 12/2017/TT-BGDDT dated May 19, 2017 of the Ministry of Education promulgating the regulation on higher education accreditation. This circular was effective as from the date of 4 July 2017. Retrieved April 5, 2020, from https://english.luatvietnam.vn/circular-no-12-2017-tt-bgddt-dated-may-192017-of-the-ministry-of-education-promulgating-the-regulation-on-higher-educationaccreditation-114461-Doc1.html

National Assembly of Vietnam. (2005). Law on Education. Retrieved April 10, 2020, from https://english.luatvietnam.vn/giao-duc/luat-giao-duc-2005-17474-d1.html

National Assembly of Vietnam. (2012). Law on Higher Education. Retrieved April 12, 2020, from https://english.luatvietnam.vn/law-no-08-2012-qh13-dated-june-18-2012-of-thegovernment-on-higher-education-71740-Doc1.html

National Assembly of Vietnam. (2018). Law amending and supplementing a number of Articles of the Law on Higher Education. Retrieved April 10, 2020, from https://english.luatvietnam.vn/law-no-34-2018-qh14-dated-november-19-2018-of-thenational-assembly-on-amendments-to-the-law-on-higher-education-169346-Doc1.html

Nitecki, D. A. (1996). Changing the concept and measure of service quality in academic libraries. The Journal of Academic Librarianship, 22(3), 181-190. doi:10.1016/S0099-1333(96)90056-7

Parasuraman, A., Zeithaml, V. A., \& Berry L. L. (1985). A conceptual model of service quality and its implications for future research. Journal of Marketing, 49(4), 41-50.

Parasuraman, A., Zeithaml, V. A., \& Berry, L. (1988). SERVQUAL: A multiple-item scale for measuring consumer perceptions of service quality. Journal of Retailing, 64(1), 12-40.

Pham, M. T. T., \& Hoang, L. D. (2017). Tiêu chi Thu viện trong Kiểm định chất luợng đại học [Criterion of Library in Tertiary Quality Accreditation]. Paper presented at the Conference minutes of Learning Resource Center, Thai Nguyen University. Retrieved April 5, 2020, from http://infolib.vnua.edu.vn/UpLoadFiles/TI\%C3\%8AU\%20CH\%C3\%8D\%20TH\%C6\%AF $\% 20$ VI\%E1\%BB\%86N\%20TRONG\%20HO\%E1\%BA\%A0T\%20\%C4\%90\%E1\%BB\%98 NG3.pdf

Pymm, B. (1998). Learn library management. Canberra, Autralia: DocMatrix Pty Ltd.

Quality Control Department - Ministry of Education and Training. (2019). Official dispatch 1668/QLCL-KĐCLGD dated 31 December 2019. Retrieved April 10, 2020, from http://cea.vnuhcm.edu.vn/images/upload/website-1/Tin-tuc/1a-CV1668-thay-the-CV-76831.12.2019-.pdf

Trung tâm Kiểm định chất lượng giáo dục Đại học Quốc Gia Thành phố Hồ Chí Minh. (n.d.). Kết quả kiểm định cấp co sở giáo dục [Result of accreditation at institutional level]. Retrieved April 10, 2020, from http://cea.vnuhcm.edu.vn/ket-qua-kiem-dinh-cap-co-so-giao-duc_p1_11_2-1_3-663.html

Trung tâm Kiểm định chất lượng giáo dục Đại học Quốc Gia Hà Nội. (n.d.). Kết quả kiểm định chất luợng Truờng Đại học [Result of accreditation at University]. Retrieved April 5, 2020, from http://www.cea.vnu.edu.vn/vi/ content/cac-truong-dai-hoc 